\title{
Species and Mating-Type Distribution of Tapesia yallundae and T. acuformis and Occurrence of Apothecia in the U.S. Pacific Northwest
}

\author{
G. W. Douhan, T. D. Murray, and P. S. Dyer
}

First and second authors: Department of Plant Pathology, Washington State University, Pullman 99164; and third author: School of Life and Environmental Sciences, The University of Nottingham, Nottingham NG7 2RD, UK.

Current address of G. W. Douhan: Department of Plant Pathology, University of California, Davis 95616.

Accepted for publication 20 March 2002.

\section{ABSTRACT}

Douhan, G. W., Murray, T. D., and Dyer, P. S. 2002. Species and matingtype distribution of Tapesia yallundae and T. acuformis and occurrence of apothecia in the U.S. Pacific Northwest. Phytopathology 92:703-709.

Eyespot of wheat is caused by the discomycete fungi Tapesia yallundae and T. acuformis. T. yallundae is considered the most important causal agent of the disease in this region but no apothecia of either species have been found in the U.S. Pacific Northwest (PNW). Two compatible isolates of T. yallundae from the PNW were used to inoculate a field plot in the fall of 1998 and apothecia developed in the spring and fall of 2000 on standing wheat stubble. In the spring of 2000, wheat stubble from eight naturally infected fields was examined for the presence of apothecia of T. yallundae and T. acuformis. Apothecia of $T$. acuformis were found in two fields but no apothecia of T. yallundae were found. This is the first report of apothecia of the eyespot pathogens occurring in the PNW. Species and mating-type distribution of T. yallundae and T. acuformis in the PNW were determined from 817 isolates collected from diseased wheat over 3 years at spatial scales ranging from within fields to across states. In all, 460 isolates were identified as $T$. yallundae and 357 isolates were identified as T. acuformis with MAT11/MAT1-2 ratios not significantly different from 1:1 based on $\chi^{2}$ tests at most scales tested. The apparent increase in frequency of $T$. acuformis from previous surveys may indicate a shift in the predominant species causing eyespot. The occurrence of apothecia under field conditions, along with the widespread distribution of mating types of both species, suggests that sexual reproduction may be occurring in both species.
Eyespot disease of cereals, caused by the discomycete fungi Tapesia yallundae and T. acuformis, is a persistent and yieldlimiting problem in many temperate climates where winter wheat is grown. Both pathogens over-summer between crops in colonized host debris and sporulate during cool and moist conditions in the fall and spring $(19,31)$. Infection and colonization of stems occurs at or near the soil line, which weakens and reduces the number of tillers, resulting in yield loss from reduced grain set and lodging $(5,31)$. In the United States, eyespot is a significant problem in the Pacific Northwest (PNW), where the disease can affect more than 500,000 ha and reduce yield by up to $50 \%$ in winter wheat-growing areas of eastern Washington, northeastern Oregon, and northern Idaho $(5,24)$. Control of eyespot relies on the use of fungicides, delayed seeding in the fall, and by planting resistant cultivars (24).

T. yallundae and T. acuformis, respectively, were previously known as W- and R-pathotypes of the anamorphic species Pseudocercosporella herpotrichoides, based on pathogenicity and cultural characteristics $(13,16)$. W-type isolates are highly virulent to wheat but weakly virulent to rye and produce fast growing colonies with smooth edges on potato dextrose agar (PDA) (19, 30). R-type isolates are equally virulent on wheat and rye and form slow-growing colonies on PDA with feathery, uneven margins $(19,30)$. Apothecia belonging to the genus Tapesia were discovered in Australia in 1987 on wheat residue (34). Single ascospore isolates derived from these apothecia yielded W-type isolates (34). Apothecia subsequently were found in England that produced R-type isolates, indicating that sexual reproduction

Corresponding author: T. D. Murray; E-mail address: tim_murray@wsu.edu

Publication no. P-2002-0513-01R

(C) 2002 The American Phytopathological Society could occur within both pathotypes and establishing the anamorph-teleomorph connection (10). A two-allele heterothallic mating system has since been described for both pathotypes $(9$, $11,22)$, which are now considered separate biological species, $T$. yallundae (W-type) and T. acuformis (R-type), based on the failure of isolates from the two groups to intercross, despite having apparently morphologically identical apothecia $(9,23)$. Additional sequence and molecular marker data supports the separation of pathotypes into distinct species $(25,28,32)$.

Apothecia of T. yallundae have been found in wheat fields in Germany, England, Belgium, Australia, New Zealand, and South Africa (19). Apothecia of T. acuformis have only been reported from England (10), Germany (14), and Belgium (22), and are generally rare compared to apothecia of $T$. yallundae $(10,19)$. In all cases, apothecia were found in agricultural fields where the stubble was left after harvest, or on diseased stubble that had been collected from the field and incubated in vitro. In England, apothecia of $T$. yallundae develop under natural field conditions when compatible isolates are used as inoculum, but apothecia of T. acuformis have not been found under similar experimental conditions (7). No apothecia of either species have been found in the U.S. PNW even though the disease has been studied intensively since the early 1900s (31).

Under laboratory conditions, apothecia of $T$. yallundae form readily when compatible mating types are crossed (11). Both mating types of $T$. yallundae recently have been identified from the PNW based on successful laboratory crosses, but only a limited number of isolates were used to determine mating type (6). In contrast, in vitro crosses between $T$. acuformis isolates rarely produce fertile apothecia $(9,19,23)$, which has made studying mating-type distribution of T. acuformis difficult. Recently, the mating-type idiomorphs of T. yallundae have been sequenced and a multiplex polymerase chain reaction (PCR) assay developed to 
identify mating types of both species (8). The ability to differentiate mating type using a simple PCR test allows for the screening of a large number of isolates more effectively than performing in vitro crosses, which can take 6 to 12 months to complete, and also allows mating type of T. acuformis to be determined.

The objectives of this research were to determine if compatible isolates of T. yallundae could produce apothecia under field conditions and to estimate the frequency of occurrence of apothecia of either species by collecting and examining naturally diseased wheat stubble from winter wheat fields in the PNW. Moreover, the distribution of mating type of both species was investigated to test if the mating type ratio of MAT1-1 to MAT1-2 was in a 1:1 ratio for both species, as would be consistent with sexually reproducing species. T. yallundae has been the predominant species causing eyespot in the PNW since the disease was first described from Washington in the early 1900s (24,31). However, T. acuformis appears to be increasing in importance based on recent surveys (G. W. Douhan and T. D. Murray, unpublished data). This apparent increase in $T$. acuformis may indicate a shift in the predominant species causing eyespot, which also occurred in some parts of Europe in the early 1980s $(13,19)$. Such a shift in the major eyespot pathogen could have an impact on disease control because little is known about resistance to T. acuformis in PNW winter wheat cultivars. Therefore, a second objective was to determine the relative abundance of each species in the PNW.

\section{MATERIALS AND METHODS}

Field inoculation. A field experiment was conducted at the Spillman Agronomy Farm, Pullman, WA, using winter wheat cvs. Madsen and Stephens and the T. yallundae isolates 90-83-5 (MAT1-1) and 97-1-8 (MAT1-2), which previously were shown to be fertile under laboratory conditions (6). Seed was sown $(50 \mathrm{~g}$ per plot) on 23 September 1998 using a grain drill. Plots were planted in five rows of approximately 1.4 by $3.0 \mathrm{~m}$ into Thatuna silt loam (fine-silty, mixed, mesic xeric Agrialboll). Six plots of each cultivar were arranged in a completely randomized design with three treatments consisting of (i) inoculation of $T$. yallundae isolate 90-83-5 (MAT1-1) alone, (ii) inoculation of T. yallundae isolate 97-1-8 (MAT1-2) alone, or (iii) a 1:1 mixture of both isolates. Inoculum was produced by placing oat kernels colonized with the fungus on fiberglass screens outdoors in the early autumn for 4 to 6 weeks $(3,4)$. Conidia were collected by rinsing the oats with water and adjusting the final concentration to $1 \times 10^{6}$ conidia

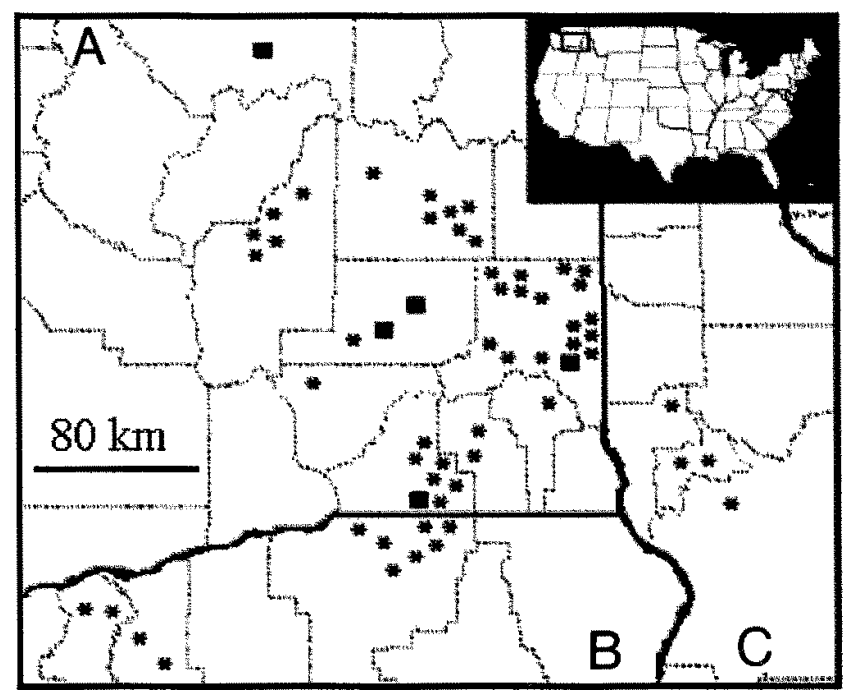

Fig. 1. Locations of eyespot samples from winter wheat fields in A, Washington, $\mathbf{B}$, Oregon, and $\mathbf{C}$, Idaho. Intensively sampled fields $=\mathbf{\square}$ and less intensively sampled fields $=*$. per ml using a hemacytometer. Inoculum was applied on $17 \mathrm{No}-$ vember at a rate of 262.5 liters/ha using a $\mathrm{CO}_{2}$-pressurized backpack sprayer. The plots were harvested during the first week of August 1999 and the stubble was left standing. The plots were examined at the end of September and October 1999 and again in March and September 2000 for the presence of apothecia by randomly sampling straw from each treatment and observing 50 stems using a stereo microscope. When apothecia were found, single ascospore cultures were made from several apothecia by placing apothecia on the underside of a petri dish lid using petroleum jelly. The lids then were placed over $1.5 \%$ water agar (WA) (Sigma-Aldrich, St. Louis) amended with rifampicin $(50 \mu \mathrm{g} / \mathrm{ml}$; Sigma-Aldrich) and ascospores were allowed to discharge for 24 to $48 \mathrm{~h}$ at room temperature $\left(20^{\circ} \mathrm{C}\right)$. Single germinated ascospores were transferred to PDA (Difco Laboratories, Detroit) 24 to $48 \mathrm{~h}$ after incubation at room temperature and incubated an additional 2 to 3 weeks at room temperature to confirm colony morphology. Apothecia also were examined microscopically to confirm their identity as T. yallundae as described by Wallwork and Spooner (34).

Field observations from naturally diseased wheat stems. Straw from eight wheat fields in Washington previously identified as having a high incidence of eyespot during the fall of 1999 was sampled on 29 March and 5 May 2000. Approximately 75 to 150 stems were randomly collected within a $25-\mathrm{m}^{2}$ area from each field. Diseased straw was collected from fields that had intact standing stubble as well as from fields where the stubble had been tilled. From 50 to 75 stems with intact lower leaf sheaths were examined for the presence of apothecia using a stereo microscope. When apothecia were found, several were examined in greater detail using a compound microscope to observe morphological characters, and single ascospore cultures were made as described above or by dilution plating crushed apothecia onto WA amended with rifampicin after microscopic examination.

Sampling of field isolates for species and mating-type distribution. A hierarchal sampling strategy was used to collect isolates of T. yallundae and T. acuformis. Five wheat fields in Washington were intensively sampled and smaller samples were collected from 55 wheat fields from eastern Washington, northern Oregon, and northern Idaho (Fig. 1; Table 1). All isolates were collected from diseased stems from March through July 1998, 1999, and 2000. Two different sampling strategies were used for the intensively sampled fields. In 1998 and 1999 , diseased plants $(\approx 20$ to 30 stems) were collected every $3 \mathrm{~m}$ along two parallel transects separated by 100 to $150 \mathrm{~m}$ for a total of $60(2 \times 30)$ and $100(2 \times$ 50) samples, respectively. In 2000 , the sampling strategy was modified and diseased plants $(\approx 10$ to 20 stems) were collected every meter along two transects separated by $3 \mathrm{~m}$ for a total of 20 $(2 \times 10)$ samples. In 1998 and 1999, an attempt was made to recover a single isolate per sample, whereas in 2000, an attempt was made to recover up to three isolates per sample. It was possible to collect samples along transects because all fields had relatively uniform disease across a large area. In contrast, individual plants were pulled randomly from the less intensively sampled fields to look for disease symptoms because aboveground symptoms were not apparent at the time of collection. Each sample was collected at least 5 to $10 \mathrm{~m}$ apart and was represented by 1 to 15 diseased stems per field with a maximum of 10 samples per field. An attempt was made to recover a single isolate per sample.

To isolate the pathogens, lesions were cut from diseased stems, surface disinfected for 1 to $3 \mathrm{~min}$ in $1 \% \mathrm{NaOCl}$, placed onto WA containing rifampicin $(50 \mu \mathrm{g} / \mathrm{ml})$, and incubated at 14 to $16^{\circ} \mathrm{C}$ under near UV light for 1 to 2 weeks. Hyphae growing directly from the lesions or hyphal tips from the edge of a colony growing into the agar were transferred to $0.2 \%$ PDA containing rifampicin $(50 \mu \mathrm{g} / \mathrm{ml})$ and incubated for an additional 1 to 2 weeks at room temperature. When isolates appearing to be $T$. yallundae and $T$. acuformis originated from the same sample, two isolates per 
sample were made, one to tentatively represent each species. Single conidial cultures were made from the intensively sampled fields but not from the less intensively sampled fields. All isolates were incubated at room temperature on PDA for at least 2 weeks before identification was made.

DNA extraction and mating-type identification. Isolates were grown on PDA for 2 to 4 weeks at room temperature, after which surface mycelium was removed and freeze dried. DNA was extracted by the method of Lee and Taylor (17) omitting the addition of 2-mercaptoethanol and using $100 \mathrm{mM}$ Tris ( $\mathrm{pH} \mathrm{8.0)} \mathrm{instead} \mathrm{of}$ $50 \mathrm{mM}$ Tris (pH 7.2) in the lysis buffer. DNA was suspended into Tris-EDTA (10 mM Tris, $0.1 \mathrm{mM}$ EDTA, $\mathrm{pH}$ 8.0) with the addition of RNAse $\left(20 \mu \mathrm{g} / \mathrm{ml}\right.$, Sigma-Aldrich), incubated at $37^{\circ} \mathrm{C}$ for $2 \mathrm{~h}$, diluted $1: 25$ in sterile $\mathrm{H}_{2} \mathrm{O}$, and used directly as template in PCR.

Mating type of isolates was determined using multiplex PCR as described by Dyer et al. (8). Three primers are used in the assay, one that is common to both mating types and specific primers for MAT1-1 and MAT1-2 sequences which are differentiated by size in agarose gels. Each 20- $\mu$ l PCR reaction contained $1 \times$ PCR buffer (Life Technologies, Grand Island, NY), $2.0 \mathrm{mM} \mathrm{MgCl}$, $2.5 \mathrm{mM}$ each dNTP (Life Technologies), $3.75 \mu \mathrm{M}$ of each primer, 0.5 units of Taq polymerase (Life Technologies), and $2 \mu \mathrm{l}$ of diluted template DNA. Thermocycling conditions consisted of an initial hold of $94^{\circ} \mathrm{C}$ for $4 \mathrm{~min}$ followed by 30 cycles of $94^{\circ} \mathrm{C}$ $(30 \mathrm{~s}), 55^{\circ} \mathrm{C}(30 \mathrm{~s})$, and $72^{\circ} \mathrm{C}(1 \mathrm{~min})$ with a final hold of $72^{\circ} \mathrm{C}$ for 5 min. All amplifications were performed in a PE-9700 thermocycler (Perkin Elmer Corp., Norwalk, CT). PCR products were separated in $1.5 \%$ agarose gels and stained with ethidium bromide, after which the image of the gel was captured digitally.

Identification of field isolates. Isolates were grown on PDA for 2 to 4 weeks at room temperature before identification was determined. T. yallundae isolates usually produce fast-growing, smoky gray colonies with smooth edges, whereas isolates of $T$. acuformis grow at about half the rate of $T$. yallundae and produce compact gray to cream-colored colonies with feathery to coarsely uneven margins (30). In instances when isolates produced intermediate cultural characteristics and positive identification could not be determined visually, isolate identification was determined using species-specific PCR primers designed from the internal transcribed spacer (ITS) region of the rDNA (2). Amplification cocktail mixture for species identification using species-specific primers was the same as above. Thermocycling conditions consisted of an initial hold of $94^{\circ} \mathrm{C}$ for 4 min followed by 30 cycles of $94^{\circ} \mathrm{C}(20 \mathrm{~s})$ to $72^{\circ} \mathrm{C}(30 \mathrm{~s})$ with a final hold of $72^{\circ} \mathrm{C}$ for $5 \mathrm{~min}$. All amplifications were performed in a PE-9700 thermocycler and the PCR products were separated in $1.5 \%$ agarose gels and stained with ethidium bromide, after which the image of the gel was captured digitally.

Data analysis of field isolates. Isolates were pooled in a hierarchical fashion to investigate species and mating-type distribution by field, county, state, and the entire PNW. Isolates from the intensively sampled fields were used to represent individual fields in Washington. Isolates from the less intensively sampled fields were pooled for county comparison, and counties were pooled for state comparisons. The entire data set was pooled to represent the PNW winter wheat-growing area. The number of isolates and mating type of $T$. yallundae and T. acuformis at all levels were determined and $\chi^{2}$ tests were used to test for deviations from the expected 1:1 ratio of MAT1-1/MAT1-2 under the null hypothesis of sexual reproduction at the $95 \%$ confidence level. The $\chi^{2}$ tests were not performed on sample sizes of less than 10 due to lack of statistical power (12).

\section{RESULTS}

Development of apothecia in inoculated field plots. Apothecia were first observed on wheat stubble 25 March 2000. In all, 51 and $94 \%$ of stems examined from cvs. Madsen and Stephens, respectively, had apothecia in the treatment where both mating types were used as inoculum. Only one apothecium was found on a stem of Stephens from a treatment where a single mating type was used as inoculum. The disease was more severe on Stephens compared to Madsen based on a large percentage of stems that had lodged in the Stephens plots. However, eyespot lesions were

TABLE 1. Isolates of Tapesia yallundae and T. acuformis from wheat fields in Washington (WA), Oregon (OR), and Idaho (ID) collected March 1998 to May 2000

\begin{tabular}{|c|c|c|c|c|}
\hline State & County & Field no. $^{a}$ & Date collected ${ }^{b}$ & $\mathrm{~N}^{\mathrm{c}}$ \\
\hline WA & Adams & $98-2 *$ & $4 / 26 / 98$ & 76 \\
\hline WA & Adams & $99-1 *$ & $4 / 29 / 99$ & 123 \\
\hline WA & Adams & $99-3$ & $3 / 31 / 99$ & 18 \\
\hline WA & Adams & $99-7$ & $3 / 31 / 99$ & 3 \\
\hline WA & Columbia & $99-21$ & $4 / 23 / 99$ & 4 \\
\hline WA & Garfield & $99-35$ & $4 / 23 / 99$ & 9 \\
\hline WA & Grant & $99-10$ & $4 / 16 / 99$ & 15 \\
\hline WA & Grant & $99-14$ & 4/16/99 & 4 \\
\hline WA & Grant & $99-16$ & 4/16/99 & 13 \\
\hline WA & Grant & $99-19$ & 4/16/99 & 8 \\
\hline WA & Grant & $99-39$ & 4/16/99 & 3 \\
\hline WA & Lincoln & $99-11$ & 4/16/99 & 12 \\
\hline WA & Lincoln & $99-12$ & 4/16/99 & 9 \\
\hline WA & Lincoln & $99-15$ & 4/16/99 & 12 \\
\hline WA & Lincoln & $99-17$ & 4/16/99 & 11 \\
\hline WA & Lincoln & $99-28$ & $4 / 13 / 99$ & 5 \\
\hline WA & Lincoln & $99-37$ & $4 / 16 / 99$ & 1 \\
\hline WA & Okanogan & $98-1 *$ & $4 / 25 / 98$ & 81 \\
\hline WA & Walla Walla & $00-1 *$ & $5 / 3 / 00$ & 55 \\
\hline WA & Walla Walla & $99-5$ & $3 / 31 / 99$ & 1 \\
\hline WA & Walla Walla & $99-6$ & $3 / 31 / 99$ & 5 \\
\hline WA & Walla Walla & $99-29$ & 4/23/99 & 9 \\
\hline WA & Walla Walla & $99-31$ & 4/23/99 & 8 \\
\hline WA & Walla Walla & $99-33$ & $4 / 23 / 99$ & 8 \\
\hline WA & Walla Walla & $99-36$ & 4/23/99 & 5 \\
\hline WA & Whitman & $00-14 *$ & $6 / 15 / 00$ & 82 \\
\hline WA & Whitman & $99-2$ & $4 / 26 / 99$ & 10 \\
\hline WA & Whitman & $99-4$ & $3 / 31 / 99$ & 9 \\
\hline WA & Whitman & $99-8$ & $4 / 13 / 99$ & 3 \\
\hline WA & Whitman & $99-9$ & 4/28/99 & 10 \\
\hline WA & Whitman & $99-18$ & $4 / 16 / 99$ & 11 \\
\hline WA & Whitman & $99-20$ & $4 / 16 / 99$ & 6 \\
\hline WA & Whitman & $99-22$ & 4/16/99 & 4 \\
\hline WA & Whitman & $99-23$ & $4 / 23 / 99$ & 16 \\
\hline WA & Whitman & $99-24$ & $4 / 16 / 99$ & 13 \\
\hline WA & Whitman & $99-38$ & 4/16/99 & 3 \\
\hline WA & Whitman & $99-40$ & 4/23/99 & 12 \\
\hline WA & Whitman & $99-41$ & 4/23/99 & 13 \\
\hline WA & Whitman & $99-42$ & 4/23/99 & 5 \\
\hline WA & Whitman & $99-43$ & $4 / 23 / 99$ & 5 \\
\hline WA & Whitman & $99-44$ & $4 / 23 / 99$ & 1 \\
\hline WA & Whitman & $00-10$ & $5 / 22 / 00$ & 10 \\
\hline WA & Whitman & $00-11$ & $5 / 22 / 00$ & 7 \\
\hline WA & Whitman & $00-12$ & $5 / 22 / 00$ & 3 \\
\hline WA & Whitman & $00-13$ & $5 / 22 / 00$ & 4 \\
\hline OR & Gilliam & $00-4$ & $5 / 23 / 00$ & 8 \\
\hline OR & Gilliam & $00-5$ & $5 / 23 / 00$ & 4 \\
\hline OR & Sherman & 00-2 & $5 / 23 / 00$ & 7 \\
\hline OR & Sherman & 00-3 & $5 / 23 / 00$ & 6 \\
\hline OR & Umatilla & $00-13$ & $4 / 23 / 99$ & 7 \\
\hline OR & Umatilla & $00-25$ & 4/23/99 & 10 \\
\hline OR & Umatilla & $00-26$ & 4/23/99 & 11 \\
\hline OR & Umatilla & $00-27$ & $4 / 23 / 99$ & 10 \\
\hline OR & Umatilla & $00-30$ & 4/23/99 & 1 \\
\hline OR & Umatilla & $00-32$ & 4/23/99 & 9 \\
\hline OR & Umatilla & $00-34$ & $4 / 23 / 99$ & 3 \\
\hline ID & Idaho & $00-8$ & $5 / 23 / 00$ & 7 \\
\hline ID & Lewis & $00-7$ & $5 / 23 / 00$ & 3 \\
\hline ID & Lewis & $00-9$ & $5 / 23 / 00$ & 10 \\
\hline ID & Nez Perce & $00-6$ & $5 / 23 / 00$ & 7 \\
\hline Total & $\ldots$ & $\ldots$ & $\ldots$ & 828 \\
\hline
\end{tabular}


readily observed on Madsen stems but no disease ratings were made on either cultivar.

Developmental stages of apothecia ranged from immature initials to fully exposed cups on the lower leaf sheaths below the first node of each cultivar. The number of mature and developing apothecia on each stem ranged from a few to several hundred, and more apothecia generally were found on cvs. Stephens than Madsen. Mature apothecia of T. yallundae also were found on 25 September 2000 on $10 \%$ of stems examined from Stephens. Apothecia were not abundant compared with the observations made the previous spring. Only one stem had a cluster of apothecia $(\approx 10)$ and the remaining four stems had one or two. No apothecia were found on stems of Madsen. The identification of apothecia belonging to the genus Tapesia was made by morphological observations and the final identification as $T$. yallundae was confirmed by cultural characteristics of progeny isolated from apothecia and by PCR as described above.

Development of apothecia under natural field conditions. One to six individual apothecia per stem were found on 2 and $4 \%$ of the sampled wheat stems collected from two fields, respectively, in the vicinity of Walla Walla, WA. Most of the apothecia were fully open, mature, and had already discharged many ascospores based on the number of empty asci and condition of the apothecia. Attempts were made to produce single ascospore cultures from all apothecia found; however, only three apothecia yielded viable cultures. The identification of apothecia belonging to the genus Tapesia was made by morphological observations and the final identification as $T$. acuformis was confirmed by cultural characteristics of progeny isolated from apothecia and by PCR as described above.

Identification and species distribution of field isolates. Problems with PCR amplification of either the mating-type locus or the ITS region were encountered with 11 isolates; therefore, data is presented for only 817 isolates (Table 1). Most isolates (789) were easily identified as T. yallundae or T. acuformis based on cultural characteristics on PDA. Only 28 isolates produced intermediate cultural characteristics and the majority of these isolates were identified as T. acuformis by PCR.

In all, 460 isolates were identified as T. yallundae and 357 as $T$. acuformis, with T. yallundae more commonly isolated at all scales sampled (Tables 2 and 3). T. yallundae and T. acuformis were isolated from all fields sampled, except for Columbia and Garfield Counties, WA, where T. yallundae was not isolated, and Gilliam and Sherman Counties, OR, where T. acuformis was not isolated (Table 3). Even though both species were widely distributed, a greater proportion of $T$. yallundae isolates were collected from southeastern Washington and northeastern Oregon compared with T. acuformis.

Mating-type distribution of field isolates. Mating type was readily identified in $T$. yallundae and $T$. acuformis following amplification of an 812-bp MAT1-1-specific product or of a 418-bp MAT1-2-specific product (Fig. 2). Mating-type ratio of MAT11/MAT1-2 for the entire PNW collection of T. yallundae was 216:244, which did not deviate significantly from a 1:1 ratio,

TABLE 2. Species and mating-type distribution of Tapesia yallundae and T. acuformis within individual fields sampled in Washington

\begin{tabular}{|c|c|c|c|c|c|c|}
\hline \multirow[b]{2}{*}{ Field } & \multicolumn{3}{|c|}{ T. yallundae } & \multicolumn{3}{|c|}{ T. acuformis } \\
\hline & Number sampled & $M A T 1-1 / M A T 1-2^{\mathrm{a}}$ & $\chi^{2 b}$ & Number sampled & $M A T 1-1 / M A T 1-2^{\mathrm{a}}$ & $\chi^{2 b}$ \\
\hline $98-1$ & 43 & $21: 22$ & 0.02 & 36 & $12: 24$ & $5.16^{*}$ \\
\hline $98-2$ & 27 & $12: 15$ & 0.34 & 49 & $22: 27$ & 0.52 \\
\hline 99-1 & 66 & $26: 40$ & 2.96 & 57 & $26: 31$ & 0.44 \\
\hline 00-1 & 46 & $12: 34$ & $10.5^{*}$ & 8 & $7: 1$ & $\ldots$ \\
\hline $00-14$ & 53 & $22: 31$ & 1.86 & 28 & $16: 12$ & 0.58 \\
\hline Total & 235 & $93: 142$ & $10.2 *$ & 178 & $83: 95$ & 0.08 \\
\hline
\end{tabular}

a Mating type determined by multiplex polymerase chain reaction (8).

${ }^{\text {b }} \chi^{2}$ value based on a 1:1 ratio with 1 degree of freedom; * indicates $P<0.05$.

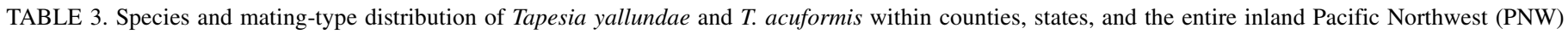
region of Washington (WA), Oregon (OR), and Idaho (ID)

\begin{tabular}{|c|c|c|c|c|c|c|}
\hline \multirow[b]{2}{*}{ State, county } & \multicolumn{3}{|c|}{ T. yallundae } & \multicolumn{3}{|c|}{ T. acuformis } \\
\hline & Number sampled & $M A T 1-1 / M A T 1-2^{\mathrm{a}}$ & $\chi^{2 b}$ & Number sampled & $M A T 1-1 / M A T 1-2^{\mathrm{a}}$ & $\chi^{2 b}$ \\
\hline \multicolumn{7}{|l|}{ WA } \\
\hline Adams & 12 & $4: 8$ & 1.34 & 9 & $4: 5$ & $\ldots$ \\
\hline Columbia & $\ldots$ & $\ldots$ & $\ldots$ & 3 & $3: 0$ & $\ldots$ \\
\hline Garfield & $\ldots$ & $\ldots$ & $\ldots$ & 9 & $4: 5$ & $\ldots$ \\
\hline Grant & 24 & $7: 17$ & $4.16^{*}$ & 19 & $10: 9$ & 0.06 \\
\hline Lincoln & 18 & $10: 8$ & 0.06 & 31 & $10: 21$ & $3.90 *$ \\
\hline Walla Walla & 25 & $17: 8$ & 2.46 & 9 & $3: 6$ & $\ldots$ \\
\hline Whitman & 64 & $40: 24$ & 4 & 79 & $35: 44$ & 1.5 \\
\hline Subtotal & 143 & $78: 65$ & 1.08 & 159 & $69: 90$ & 3.18 \\
\hline \multicolumn{7}{|l|}{ OR } \\
\hline Gilliam & 12 & $8: 4$ & 1.34 & $\ldots$ & $\ldots$ & $\ldots$ \\
\hline Sherman & 13 & $4: 9$ & 1.92 & $\ldots$ & $\ldots$ & $\ldots$ \\
\hline Umatilla & 42 & 25 & 1.14 & 8 & $1: 7$ & $\ldots$ \\
\hline Subtotal & 67 & $37: 30$ & 0.66 & 8 & $1: 7$ & $\ldots$ \\
\hline \multicolumn{7}{|l|}{ ID } \\
\hline Idaho & 5 & $2: 3$ & $\ldots$ & 2 & $1: 1$ & $\ldots$ \\
\hline Lewis & 4 & $2: 2$ & $\ldots$ & 9 & $5: 4$ & $\ldots$ \\
\hline Nez Perce & 6 & $4: 2$ & $\ldots$ & 1 & $0: 1$ & $\ldots$ \\
\hline Subtotal & 15 & $8: 7$ & 0.06 & 12 & $6: 6$ & 0 \\
\hline Total & 225 & $123: 102$ & 1.96 & 179 & $76: 103$ & $4.08 *$ \\
\hline PNW total ${ }^{c}$ & 460 & $216: 244$ & 1.70 & 357 & $159: 198$ & $4.26^{*}$ \\
\hline
\end{tabular}

${ }^{a}$ Mating type determined by multiplex polymerase chain reaction (8).

b $\chi^{2}$ value based on a 1:1 ratio with 1 degree of freedom, * indicates $P<0.05$.

${ }^{c}$ Entire PNW total including results from Table 2. 
whereas the MAT1-1/MAT1-2 ratio for T. acuformis was 159:198, which did deviate significantly from a 1:1 ratio (Table 3 ). With the exception of $T$. yallundae population 00-1 and T. acuformis population 98-1, the ratio of mating types for field populations of $T$. yallundae and T. acuformis in Washington did not deviate significantly from 1:1 (Table 2). Only two county comparisons, one each for T. yallundae and T. acuformis, deviated significantly from a 1:1 ratio (Table 3 ). Both mating types of each species were widely distributed across all sampling scales studied in the U.S. PNW. Sample sizes for county and state comparisons in Oregon and Idaho were small compared with most of the Washington samples, which prevented statistically meaningful $\chi^{2}$ tests for some samples; however, 1:1 ratios still were apparent in most comparisons for T. yallundae and T. acuformis (Table 3).

\section{DISCUSSION}

This is the first report of apothecia of T. yallundae and $T$. acuformis occurring under field conditions in the U.S. PNW. Apothecia of T. acuformis were found under natural field conditions, whereas apothecia of T. yallundae were found in a field plot inoculated with isolates of compatible mating type. The discovery of apothecia of $T$. acuformis under natural field conditions was unexpected because apothecia of T. acuformis are rare compared with T. yallundae in other parts of the world (19). The role of apothecia of either pathogen in the eyespot disease cycle in the PNW is unknown. The formation of apothecia could serve as a source of primary inoculum, long-distance dispersal of inoculum, and in generating increased genotypic variation through recombination (21).

Epidemics of eyespot are dependent upon the amount of primary inoculum and environmental conditions, particularly temperature and moisture $(19,29,31)$. Fall infections are generally more important in the PNW than spring infections because the environmental conditions are usually favorable for disease development, but spring infections also can result in severe eyespot (29). The primary source of inoculum for eyespot under PNW conditions has been attributed to conidia produced on infested residue during the fall and spring. However, it is now apparent that apothecia can form under PNW field conditions, making ascospores a potential source of inoculum. Apothecia first were observed in early spring on stubble in the inoculated field plot and on stubble of naturally infected plants, indicating they could be a potential source of inoculum for spring infections. However, apothecia with viable ascospores also were found the following fall in the inoculated field plot, indicating they also could be a potential source of inoculum in the fall because they developed on host residue over two growing seasons. Apothecia may have not developed in the fall of 1999, the first year after harvest, because of the unusually dry conditions. Only $0.8 \mathrm{~mm}$ of precipitation was recorded in September 1999 compared with $41.1 \mathrm{~mm}$ in September 2000 and $32.4 \mathrm{~mm}$ in September averaged over the proceeding 5 years, excluding 1999 (weather data from the Spillman Agronomy Farm, Pullman, WA). Therefore, in a more typical year, apothecia may develop in the fall following harvest and continue to develop into the spring, as was found in the United Kingdom, where apothecia of $T$. yallundae capable of discharging viable ascospores developed over a 6-month period following harvest in plots inoculated with compatible mating types (7).

Additional evidence supporting the potential for sexual reproduction to occur regularly in the PNW was the widespread distribution of compatible mating types of both $T$. yallundae and $T$. acuformis in wheat fields sampled over 3 years. However, reproductive inferences drawn from mating-type data alone should be made with caution $(21,27)$. PCR tests based on conserved matingtype regions have revealed the presence of both MAT1-1 and MAT1-2 isolates in field populations of supposedly asexual fungi for which no sexual stage has yet been described (1), and skewed segregation ratios of sexually reproducing fungi may be the result of selection acting on the mating type or a closely linked locus $(21,27)$. Additionally, deviations from the expected 1:1 ratio of mating types in sexually reproducing fungi also may be the result of repeated isolation of clonal genotypes due to prolific asexual reproduction (21), which was the case for $T$. yallundae population 00-1 based on the analysis of molecular markers (G. W. Douhan and T. D. Murray, unpublished data). This also may explain some of the deviations from the 1:1 ratio of mating type in T. acuformis in this study.

The ability of $T$. yallundae and $T$. acuformis to sexually reproduce also will depend on factors besides the presence of both mating types within a population, such as fertility between compatible isolates, the presence of suitable substrates, and proper environmental conditions. Apothecia of both species can develop under PNW field conditions and both mating types were found in approximately equal proportions at all geographic scales sampled;
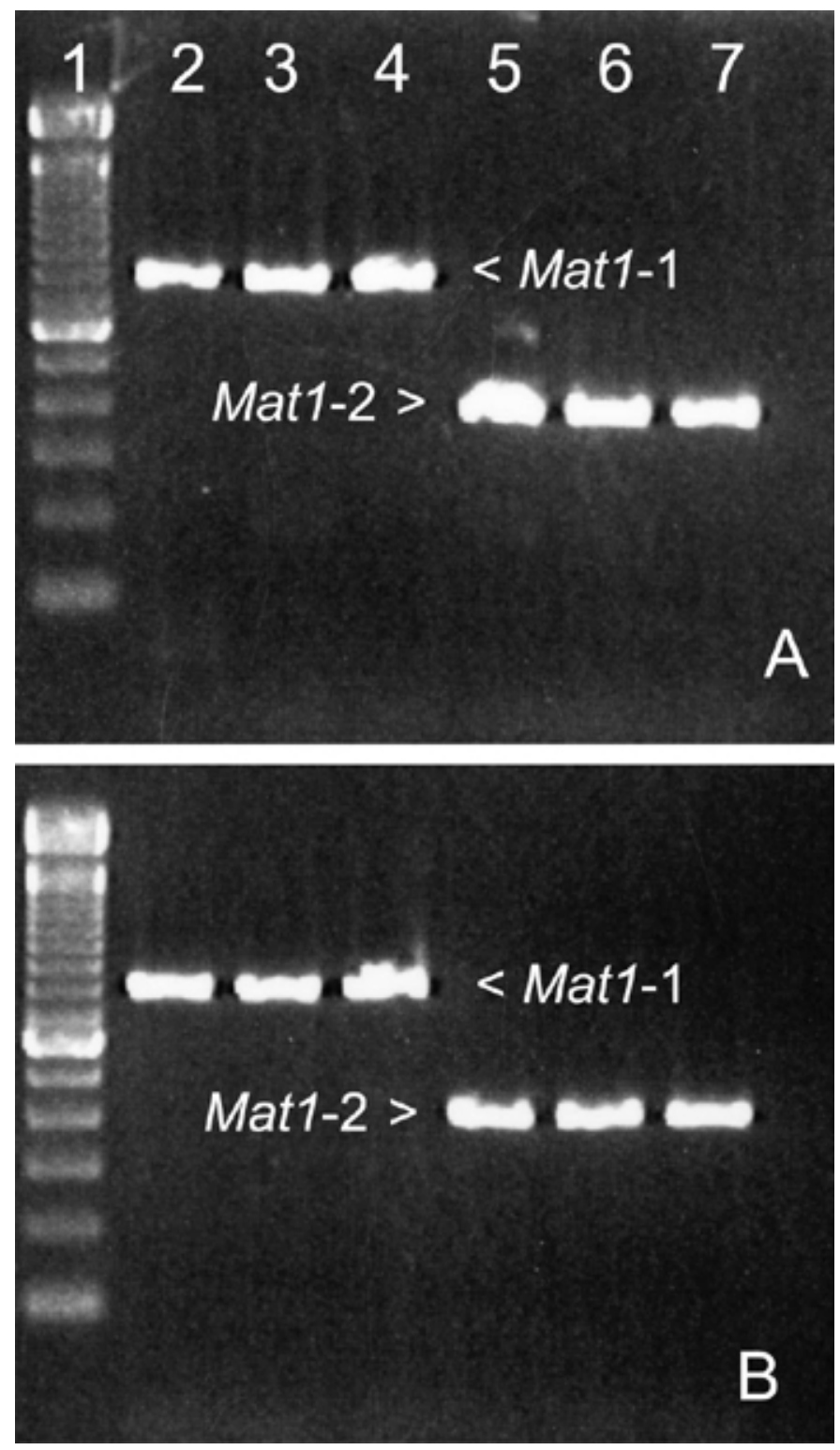

Fig. 2. Multiplex polymerase chain reaction detection of mating type of Tapesia yallundae and T. acuformis (8). Three primers were used in all reactions; one primer common to both mating type regions and a primer specific for MATI1 and MAT1-2 sequences. The MAT1-1-specific product is $418 \mathrm{bp}$ and the MAT1-2-specific product is $812 \mathrm{bp}$. Lanes 2 through 7 in the upper gel are six representative T. yallundae isolates and lanes 2 through 7 in the lower gel are six representative $T$. acuformis isolates. Lane 1 in both gels contains a 100-bp ladder (Life Technologies, Grand Island, NY). 
therefore, fertility between compatible mating types may be the only factor limiting apothecial development. Fertility may be a population-specific phenomenon (15) and additional genes that segregate independent of mating type may be involved in ascocarp production, as has been determined in the rice pathogen Magnaporthe grisea (20). It is not known if such a phenomenon exists in T. yallundae or T. acuformis.

Apothecia from naturally diseased plants were found only on standing stubble and not on stubble that had been cultivated. Although this observation was made from a relatively small sample, it is consistent with previous reports (7). Apothecia were found only on host residue that had over-summered and not on living green tissues. Other cereal pathogens, such as Mycosphaerella graminicola, Leptosphaeria nodorum, and Pyrenophora teres, also require the presence of stubble or residue for sexual reproduction to occur under field conditions (7). An increase in apothecial development in Europe has been attributed to a setaside policy implemented in 1988 and revised in 1992 that has resulted in large areas with standing wheat stubble (19). In the PNW, increased no-till farming for soil conservation purposes and the elimination of stubble burning for environmental reasons may give the eyespot pathogens more opportunity to reproduce sexually by providing a suitable substrate.

T. yallundae and T. acuformis accounted for 56 and $44 \%$, respectively, of the total eyespot pathogen isolates collected over 3 years in the PNW and represents a significant increase in the occurrence of $T$. acuformis in the PNW compared with previous studies (24). Murray (24) found that approximately $82 \%$ of 677 eyespot isolates collected in 1989-90 were T. yallundae. There was a similar increase in frequency of $T$. acuformis in some parts of Europe in the 1980s $(13,19)$. It is unknown if a similar transition is occurring in the PNW or why T. acuformis has increased over the past 10 years, but this change could have a significant impact on the management of eyespot. Little is known about the virulence of $T$. acuformis on the winter wheat cultivars currently grown in the PNW. Fungicide application practices in the PNW have been developed specifically for T. yallundae and it is unclear if $T$. acuformis isolates from the PNW respond similarly to these fungicides or if a greater potential for resistance development exists in this species.

The apparent shift in eyespot populations from T. yallundae to T. acuformis in many parts of Europe has been attributed to differential resistance to fungicides and host preference $(13,19,24)$. The two most common classes of fungicides used to control eyespot are benzimidazoles and sterol demethylation inhibitors (DMIs) (19). Resistance to DMIs in Tapesia spp. has not been reported from the PNW, but has been reported in Europe (18). Leroux and Gredt (18) found that T. acuformis is intrinsically less sensitive toward most DMIs compared with $T$. yallundae, which could have facilitated the increase of T. acuformis in Europe. The increase of $T$. acuformis populations in the PNW may be attributed to selection due to the use of DMIs for control of eyespot, although this seems unlikely due to the small acreage of winter wheat treated in the PNW compared with the total area surveyed where T. acuformis was found. It has also been suggested that the production of more winter barley in Europe may have selected for T. acuformis because T. yallundae is less virulent on barley than T. acuformis (13). However, T. yallundae is still predominant in some areas of Europe and there is no clear explanation for the distribution of these pathogens in Europe (24). In the PNW, barley is grown on less than one-quarter of the small grain acreage and it has not significantly increased over the past 10 years (35), making host preference an unlikely explanation for the increase of T. acuformis in the PNW.

An alternative explanation for the increase in frequency of $T$. acuformis in the PNW may be its ability to preferentially colonize winter wheat cultivars with eyespot resistance more successfully than T. yallundae. The resistance gene Pchl is the only known source of eyespot resistance in commercially grown PNW winter wheat (24), which saves PNW farmers approximately $\$ 4$ to 6 million per year in reduced fungicide applications (T. D. Murray, unpublished data). The majority of research in screening for resistance in the PNW has used T. yallundae as an inoculum source and the effectiveness of Pchl against T. acuformis has not been accurately investigated. Preliminary data suggests that $T$. acuformis is more virulent than T. yallundae against Madsen, the most widely grown eyespot resistant winter wheat (G. W. Douhan and T. D. Murray, unpublished data). Additionally, resistance to $T$. acuformis has been found only in Dasypyrum villosum (33) and the genetic control of resistance in this wheat relative differed between $T$. acuformis and T. yallundae. Therefore, the effectiveness of $P$ chl and newly found resistance genes should be evaluated against both species when new cultivars are developed, especially because T. acuformis is now common throughout the PNW.

In conclusion, T. acuformis has increased significantly in recent years, apothecia of both species can develop under field conditions, and both mating types of each species are widely distributed. These results suggest that $T$. acuformis is more important than previously thought and that sexual reproduction may occur in both species. Additionally, some populations of $T$. yallundae and $T$. acuformis from the intensively sampled fields in this study have a genetic structure consistent with random mating based on multilocus analysis of amplified fragment length polymorphic and mating type markers (G. W. Douhan and T. D. Murray, unpublished data). However, multiple-year studies with more intensive sampling are needed to understand the temporal importance of the species composition in the PNW and to establish the timing and frequency of apothecial development to better understand the importance of the sexual stages in the disease cycle of the eyespot pathogens in the PNW.

\section{ACKNOWLEDGMENTS}

Plant Pathology New Series 0311, College of Agriculture and Home Economics Research Center, Project 0669, Washington State University, Pullman 99164-6430. We thank the Washington State Wheat Commission for financial support for G. W. Douhan and T. D. Murray and the Biotechnology and Biological Sciences Research Council, UK (a David Phillips Research Fellowship) for financial support for P. S. Dyer.

\section{LITERATURE CITED}

1. Arie, T., Kaneko, I., Yoshida, T., Noguchi, M., Nomura, Y., and Yamaguchi, I. 2000. Mating-type genes from asexual phytopathogenic ascomycetes Fusarium oxysporum and Alternaria alternata. Mol. PlantMicrobe Interact. 13:1330-1339.

2. Beck, J. J., Beebe, J. R., Stewart, S. J., Bassin, C., and Etienne, L. 1996. Colorimetric PCR and ELISA diagnostics for the detection of Pseudocercosporella herpotrichoides in field samples. Pages 221-226 in: Proc. Bright. Crop Prot. Conf. Br. Crop Prot. Coun., Farnham, UK.

3. Bruehl, G. W., and Machtmes, R. 1985. Production of Pseudocercosporella herpotrichoides spores. Plant Dis. Rep. 69:862-863.

4. Bruehl, G. W., and Nelson, W. L. 1964. Technique for mass inoculations of winter wheat in the field with Cercosporella herpotrichoides. Plant Dis. Rep. 48:863-865.

5. Bruehl, G. W., Nelson, W. L., Koehler, F., and Vogel, O. A. 1968. Experiments with Cercosporella foot rot (strawbreaker) disease of winter wheat. Wash. Exp. Stn. Bull. 694.

6. Douhan, G. W., and Murray, T. D. 2000. Occurrence of mat-1 and mat-2 isolates of Tapesia yallundae, cause of eyespot of wheat in the U.S. Pacific Northwest. (Abstr.) Phytopathology 90(suppl.):S118.

7. Dyer, P. D., Bateman, G., and Wood, H. M. 2001. Development of apothecia of the eyespot pathogen Tapesia on cereal crop stubble residue in England. Plant Pathol. 50:356-362.

8. Dyer, P. D., Furneaux, P. A., Douhan, G. W., and Murray, T. D. 2001. A multiplex PCR test for determination of mating-type applied to the plant pathogens Tapesia yallundae and Tapesia acuformis. Fungal Gen. Biol. 33:173-180.

9. Dyer, P. S., Nicholson, P., Lucas, J. A., and Peberdy, J. F. 1996. Tapesia acuformis as a causal agent of eyespot disease of cereals and evidence for a heterothallic mating system using molecular markers. Mycol. Res. 
100:1219-1226.

10. Dyer, P. S., Papaikonomou, M., Lucus, J. A., and Peberdy, J. F. 1994. Isolation of R-type progeny of Tapesia yallundae from apothecia on wheat stubble in England. Plant Pathol. 43:1039-1044.

11. Dyer, P. S., Rezanoor, H. N., Lucus, J. A., and Peberdy, J. F. 1993. Twoallele heterothallism in Tapesia yallundae, the teleomorph of the cereal eyespot pathogen Pseudocercosporella herpotrichoides. Phys. Mol. Plant Pathol. 43:403-14.

12. Fincham, J. R. S., and Day, P. R. 1963. Fungal Genetics. 3rd ed. Blackwell Scientific Publication, Oxford, UK.

13. Hollins, T. W., Scott, P. R., and Paine, J. R. 1985. Morphology, benomyl resistance and pathogenicity to wheat and rye isolates of Pseudocercosporella herpotrichoides. Plant Pathol. 34:369-379.

14. King, A. C. 1990. The first report of Tapesia yallundae as the teleomorph of Pseudocercosporella herpotrichoides var. acuformis and its occurrence in the Federal Republic of Germany. Plant Pathol. 39:4449.

15. Kolmer, J. A., and Ellingboe, A. E. 1988. Genetic relationships between fertility and pathogenicity and virulence to rice in Magnaporthe grisea. Can. J. Bot. 66:891-897.

16. Lange-de la Camp, M. 1966. Die Wirkungsweise von Cercosporella herpotrichoides Fron Dem erreger der Halmbruchkrankheit des Getreides. II. Agressivitat des Erregers. Phytopathol. Z. 56:155-190.

17. Lee, S. B., and Taylor, J. W. 1990. Isolation of DNA from fungal mycelia and single spores. Pages 282-287 in: PCR Protocol: A Guide to Methods and Applications. Academic Press, San Diego, CA.

18. Leroux, P., and Gredt, M. 1997. Evolution of fungicide resistance in the cereal eyespot fungi Tapesia yallundae and Tapesia acuformis in France. Pestic. Sci. 51:321-327.

19. Lucas, J. A., Dyer, P. S., and Murray, T. D. 2000. Pathogenicity, hostspecificity, and population biology of Tapesia spp., causal agents of eyespot disease of cereals. Adv. Bot. Res. 33:225-258.

20. Mekwatanakarn, P., Kositratana, W., Phromraksa, T., and Zeigler, R. S. 1999. Sexually fertile Magnaporthe grisea rice pathogens in Thailand. Plant Dis. 83:939-943.

21. Milgroom, M. G. 1996. Recombination and the multilocus structure of fungal populations. Annu. Rev. Phytopathol. 34:457-477.

22. Moreau, J. M., and Maraite, H. 1995. Bipolar heterothallism in Tapesia yallundae for the two varieties of the anamorph Pseudocercosporella herpotrichoides. Mycol. Res. 99:76-80.

23. Moreau, J. M., and Maraite, H. 1996. Evidence for a heterothallic mating system in Tapesia acuformis using benomyl sensitivity and esterase isoenzyme profiles. Mycol. Res. 100:1227-1236.

24. Murray, T. D. 1996. Resistance to benzimidazole fungicides in the cereal eyespot pathogen, Pseudocercosporella herpotrichoides, in the Pacific Northwest 1984-1990. Plant Dis. 80:19-23.

25. Nicholson, P., and Rezanoor, H. N. 1994. The use of random amplified polymorphic DNA to identify pathotype and detect variation in Pseudocercosporella herpotrichoides. Mycol. Res. 98:13-21.

26. Nicholson, P., Rezanoor, H. N., Simpson, D. R., and Joyce, D. 1997. Differentiation and quantification of the cereal eyespot fungi Tapesia yallundae and Tapesia acuformis using a PCR assay. Plant Pathol. 46:842-856.

27. Oudemans, P. V., Alexander, H. M., Antonovics, J., Altizer, S., Thrall, P. H., and Rose, L. 1998. The distribution of mating-type bias in natural populations of the anther-smut Ustilago violacea on Silene alba in Virginia. Mycologia 90:372-381.

28. Poupard, P., Simonet, P., Cavelier, N., and Bardin, R. 1993. Molecular characterization of Pseudocercosporella herpotrichoides isolates by amplification of ribosomal DNA internal transcribed spacers. Plant Pathol. 42:873-881.

29. Rowe, R. C., and Powelson, R. L. 1973. Epidemiology of Cercosporella footrot of wheat: Disease spread. Phytopathology 63:984-988.

30. Scott, P. R., and Hollins, T. W. 1980. Pathogenic variation in Pseudocercosporella herpotrichoides. Ann. Appl. Plant Biol. 78:269-279.

31. Sprague, R. 1934. Cercosporella foot rot of winter cereals. U.S. Dep. Agric. Tech. Bull. No. 428.

32. Takeuchi, T., and Kuninaga, S. 1996. Determination of relationships in Pseudocercosporella herpotrichoides by analysis of mitochondrial DNA. Mycol. Res. 100:693-701.

33. Uslu, E., Miller, T. E., Rezanoor, N. H., and Nicholson, P. 1998. Resistance of Dasypyrum villosum to the cereal eyespot pathogens, Tapesia yallundae and Tapesia acuformis. Euphytica 103:203-209.

34. Wallwork, H., and Spooner, B. 1988. Tapesia yallundae-the teleomorph of Pseudocercosporella herpotrichoides. Trans. Br. Mycol. Soc. 91:703-705.

35. Washington Agricultural Statistics Service. 2000. Washington Agriculural Statistics. Olympia, WA. 